\title{
Comparative fitness of a wild squash species and three generations of hybrids between wild $\times$ virus-resistant transgenic squash
}

\author{
Marc FUCHS $^{1 *}$, Ellen M. CHIRCO ${ }^{2}$, Jim R. MCFERSON ${ }^{3 * \star}$ and Dennis GONSALVES ${ }^{1 * \star *}$ \\ ${ }^{1}$ Department of Plant Pathology, Cornell University, New York State Agricultural Experiment Station, Geneva, NY 14456, USA \\ ${ }^{2}$ Department of Horticultural Sciences, Cornell University, New York State Agricultural Experiment Station, Geneva, NY 14456, USA \\ ${ }^{3}$ Plant Genetic Resources, USDA-ARS, Cornell University, Geneva, NY 14456, USA
}

\begin{abstract}
We compared some fitness components of the wild squash species Cucurbita pepo spp. ovifera var. texana (C. texana) and three generations of hybrids (F1, BC1, and $\mathrm{BC} 2)$ between $C$. texana and commercial transgenic squash CZW-3 over three consecutive years under field conditions of low (LDP) and high disease pressure (HDP) by Cucumber mosaic virus (CMV), Zucchini yellow mosaic virus (ZYMV) and Watermelon mosaic virus (WMV). Transgenic squash CZW-3 expresses the coat protein (CP) genes of CMV, ZYMV, and WMV, and is resistant to these three aphid-borne viruses. Across all HDP trials, transgenic BC1 and BC2 hybrids expressing the three CP genes grew more vigorously, displayed resistance to CMV, ZYMV, and WMV, and produced a greater number of mature fruits and viable seeds than nontransgenic hybrid segregants and $C$. texana. Transgenic F1 hybrids behaved similarly to $\mathrm{BC} 1$ and $\mathrm{BC} 2$ hybrids but grew less vigorously than $C$. texana. In contrast, across all LDP trials, C. texana outperformed the transgenic and nontransgenic hybrid segregants. Further, only one back cross was necessary to recover individuals with most of the $C$. texana characteristics and yet maintain virus resistance. Our data suggest that $C$. texana acquiring $C P$ transgenes upon hybridization and introgression could have a selective advantage if CMV, ZYMV, and WMV are severely limiting the growth and reproductibility of wild squash populations.
\end{abstract}

Key words: Risk assessment / gene flow / transgenic squash CZW-3 / Cucurbita texana / hybrids / fitness evaluation / selection pressure / Cucumber mosaic virus / Zucchini yellow mosaic virus / Watermelon mosaic virus / virus resistance

\section{INTRODUCTION}

In the last decade, many agronomically important crops have been genetically engineered for virus resistance. The majority of virus-resistant transgenic crops developed so far result from the application of the concept of parasitederived resistance (Sanford and Johnston, 1985) and the use of viral coat protein (CP) genes (Fuchs and Gonsalves, 1997; Grumet, 1994). The efficacy of CP genes at protecting transgenic crops from deleterious effects of viruses has been extensively demonstrated in the field
(Fuchs and Gonsalves, 1997) and a few virus-resistant transgenic crops have been commercialized in the United States. Transgenic crookneck squash (Cucurbita pepo spp. ovifera var. ovifera) lines ZW-20 and CZW-3 have been deregulated (Acord, 1996; Medley, 1994) and cultivars deriving from these lines have been released (Quemada, 1998; Tricoli et al., 1995). Transgenic squash lines ZW-20 and CZW-3 are resistant to some major viruses [ZW-20 is resistant to Zucchini yellow mosaic

\footnotetext{
* Corresponding author: fuchs@colmar.inra.fr

Present address: Institut National de la Recherche Agronomique, Unité Mixte de Recherche Vigne et Vins d'Alsace, Laboratoire de Virologie, 28 rue de Herrlisheim, 68021 Colmar, France

** Present address: Washington State University, Tree Fruit Research and Extension Center, 1719 Springwater Avenue, Wenatchee, WA 98801, USA

*** Present address: Pacific Basin Agricultural Research Center, PWA-ARS-USDA, 99 Aupuni Street, Ste 204, Hilo, Hawaii 96720, USA
} 
virus (ZYMV) and Watermelon mosaic virus (WMV), and CZW-3 is resistant to ZYMV, WMV, and Cucumber mosaic virus (CMV)] because they express the $\mathrm{CP}$ genes of the respective challenge viruses (Fuchs and Gonsalves, 1995; Fuchs et al., 1998; Quemada, 1998; Tricoli et al., 1995). Also, transgenic papaya that expresses the CP gene of Papaya ringspot virus (PRSV) and is resistant to PRSV is widely grown in Hawaii (Gonsalves, 1998).

One of the major environmental safety issues over transgenic crops relates to the consequences of gene flow into wild relatives in regard to increased fitness and enhanced weediness (Dale, 1992; Hancock et al., 1996; Kareiva et al., 1994; Raybould, 1999; Rissler and Mellon, 1996; Snow and Palma, 1997). Indeed, genetically engineered crops, as well as conventionally bred crops, have the potential to spontaneously hybridize with their sexually compatible wild, i.e. plants that are growing and reproducing with no deliberate planting (Ellstrand et al., 1999), and weedy, i.e. plants that interfere with human activities (Ellstrand et al., 1999), relatives which grow sympatrically (Dale, 1992; Ellstrand et al., 1999; Hancock et al., 1996; Kareiva et al., 1994; Raybould, 1999; Rissler and Mellon, 1996; Snow and Palma, 1997). In the case of virus-resistant transgenic crops, CP genes, which confer virus resistance, can be transferred through pollen flow to wild relatives. As a consequence, the dissemination of CP transgenes could provide a selective advantage to wild species and eventually turn them into noxious weed pests (Rissler and Mellon, 1996). In addition, the dissemination of CP transgenes could induce a loss of biodiversity and a disruption of natural ecosystem balance in centers of origin for plant species.

In the companion paper (Fuchs et al., 2004), we reported on the dissemination of $\mathrm{CP}$ transgenes through pollen flow from transgenic squash CZW-3 into the wild relative $C$. pepo spp. ovifera var. texana (Decker, 1988; Kirkpatrick and Wilson, 1988; Wilson, 1990) (referred to here as C. texana) under field conditions. Introgression of the CP and NPT II genes occurred into $C$. texana from transgenic F1 hybrids resulting from hybridization of transgenic squash CZW-3 and $C$. texana. The rate of introgression increased with overlapping flowering patterns of transgenic F1 hybrids and C. texana, and with a high ratio $(1: 8$ vs. 1:24) of transgenic F1 hybrids to $C$. texana. More importantly, the movement of transgenes continuously occurred over three generations under conditions of low disease pressure (LDP) but not under conditions of high disease pressure (HDP) by CMV, ZYMV, and WMV. As a consequence, the transfer of CP genes provided $C$. texana with resistance to $\mathrm{CMV}, \mathrm{ZYMV}$, and WMV (Fuchs et al., 2004). In that study, we did not examine whether virus resistance would affect fitness characteristics of hybrid progeny that acquired the $\mathrm{CP}$ transgenes.

The present study was conducted to evaluate some fitness components of hybrids between transgenic squash CZW-3 and C. texana as introgression continued to occur into $C$. texana. Comparative fitness of three generations of transgenic and nontransgenic $C$. texana $\times \mathrm{CZW}-3$ hybrid segregants was assessed in the field under conditions of LDP and HDP in regard to flowering and fruiting phenology, plant vigor, fruit and seed production, and virus resistance.

\section{RESULTS}

\section{Plant material and identification of transgenic segregants in C. texana $\times$ CZW-3 hybrid progeny}

The commercial transgenic squash (Cucurbita pepo spp. ovifera var. ovifera) CZW-3 was used as initial donor of transgenic pollen. Plants of line CZW-3 express the CP genes of CMV, ZYMV, and WMV, and the neomycin phosphotransferase II (nptII) gene (Tricoli et al., 1995). The wild squash $C$. pepo spp. ovifera var. texana (C. texana) (Decker, 1988; Kirkpatrick and Wilson, 1988; Wilson, 1990) was used as recipient of transgenic pollen. Hybrids of $C$. texana and transgenic squash CZW-3 were developed by hand pollination in the greenhouse to ensure the recovery of viable seeds for all the desired crosses and to prevent uncontrolled dispersal of pollen. F1 hybrids (C. texana $\times \mathrm{CZW}-3$ ) were obtained in 1994 as described in our companion paper (Fuchs et al., 2004). Subsequent hybrid progeny were developed by successive back crosses into $C$. texana with transgenic $\mathrm{F} 1$ and $\mathrm{BC} 1$ segregants as staminate parents, and C. texana as pistillate parents.

Three of the five genotypes tested, F1, BC1, and BC2, were hybrid progeny between $C$. texana and transgenic squash CZW-3 (Tab. 1). These genotypes segregated for the presence of the $\mathrm{CP}$ and $n p t I I$ genes because the progeny of transgenic squash line CZW-3 used in this study was hemizygous for the transgenes (Fuchs et al., 2004). Therefore, transgenic and nontransgenic C. texana $\times$ CZW-3 hybrid segregants were identified by detecting the expression of the NPT II protein by enzyme linkedimmunosorbent assay (ELISA) prior to the transplanting. Transgenic segregants had optical density readings that were prominent and easily distinguishable from those of nontransgenic segregants $\left(\mathrm{OD}_{405 \mathrm{~nm}}\right.$ of 0.625 vs. 0.095 after $15 \mathrm{~min}$ substrate hydrolysis). As expected, a close to 1:1 segregation ratio was obtained for the three hybrid 
Fitness of virus resistance in squash

Table 1. Characteristics of the squash genotypes used in comparative fitness evaluation experiments over three consecutive years.

\begin{tabular}{|c|c|}
\hline Genotype & Characteristics and properties \\
\hline $\begin{array}{l}\text { C. texana (Cucurbita pepo spp. ovifera } \\
\text { var. texana) }\end{array}$ & $\begin{array}{l}\text { A wild squash species that readily hybridizes with } C \text {. pepo species, including transgenic } \\
\text { squash line } \mathrm{CZW}-3 \text {. C. texana was used as recipient of transgenic pollen. }\end{array}$ \\
\hline CZW-3 & $\begin{array}{l}\text { A transgenic squash line that expresses the CP genes of CMV, ZYMV, and WMV, and } \\
\text { the nptII marker gene. Transgenic line CZW-3 was used as initial donor of pollen. }\end{array}$ \\
\hline $\mathrm{F} 1$ hybrids $=$ C. texana $\times \mathrm{CZW}-3$ & The progeny of a cross between C. texana and CZW-3. \\
\hline $\mathrm{BC} 1$ hybrids $=C$. texana $\times($ C. texana $\times \mathrm{CZW}-3)$ & The first back cross progeny of $\mathrm{F} 1$ hybrids into $C$. texana. \\
\hline $\begin{array}{l}\text { BC2 hybrids }=\text { C. texana } \times[\text { C. texana } \times \\
(\text { C. texana } \times \mathrm{CZW}-3)]\end{array}$ & The second back cross progeny of $\mathrm{F} 1$ hybrids into $C$. texana. \\
\hline
\end{tabular}

progeny. For example, 265 of $550 \mathrm{~F} 1,272$ of $680 \mathrm{BC} 1$, and 374 of 817 BC2 plants reacted positively in NPTII ELISA in 1997. The presence of the CP genes of CMV, ZYMV, and WMV was confirmed by polymerase chain reaction in DNA preparations from a few selected NPT II-positive hybrids of the $\mathrm{F} 1, \mathrm{BC} 1$, and $\mathrm{BC} 2$ progeny using appropriate oligonucleotides (data not shown).

\section{Objectives and rationale of the field experiments}

Field experiments were designed to: (1) evaluate the resistance to CMV, ZYMV, and WMV in F1, BC1, and $\mathrm{BC} 2$ hybrid progeny of $C$. texana and transgenic $\mathrm{CZW}-3$, (2) compare the relative fitness of $C$. texana, and $\mathrm{F} 1$, $\mathrm{BC} 1$, and $\mathrm{BC} 2$ using as parameters: flowering and fruiting phenology, fruit and seed production, and shoot length, and (3) determine how many generations of back crosses are necessary to recover most of the C. texana characteristics and yet maintain resistance to the three target viruses, CMV, ZYMV, and WMV.

Field experiments were carried out over three consecutive years under conditions of LDP and HDP. Conditions of LDP were achieved by transplanting healthy plants in fields isolated from sources of aphid-transmissible viruses. Conditions of HDP were obtained by transplanting a few mechanically-inoculated C. texana $(20 \%$ of the total number of test plants) which were used as sources of CMV, ZYMV, and WMV for aphid-mediated spread. Thus, conditions of HDP were achieved by mechanical and vector-mediated infections.

Field experiments were designed to directly compare, in the same plots, C. texana, transgenic squash CZW-3, transgenic and nontransgenic hybrid progeny from the initial hybridization as well as the succeeding back crosses (Tab. 1). Field trials were conducted in 1995, 1996, and 1997, adding one more hybrid progeny each year. Complete randomized block designs were used for each experiment, which consisted of four blocks, and genotypes were randomly assigned within each block. Since no significant differences were observed among blocks, data were pooled.

\section{Differences in flowering and fruiting habits of C. texana, CZW-3, and C. texana $\times \mathbf{C Z W - 3}$ hybrids}

Flowering and fruiting phenology of C. texana, transgenic squash CZW-3, and three generations of transgenic and nontransgenic C. texana $\times \mathrm{CZW}-3$ hybrid segregants were visually monitored under conditions of LDP and HDP.

Transgenic squash CZW-3 developed flowers and fruits before $C$. texana under conditions of LDP: $3 \mathrm{vs}$. 6 weeks and 4 vs. 7-8 weeks after transplanting for flower and fruit production, respectively. Intermediate trends were noticed for hybrids relative to transgenic squash CZW-3 and C. texana, with each back cross progeny flowering/fruiting about one week closer to $C$. texana. F1, BC1, and BC2 hybrids developed flowers 4, 45 , and 5-6 weeks after transplanting respectively, and developed fruits 5, 5-6, and 6-7 weeks after transplanting, respectively. These results indicate that the probability to recover $C$. texana characteristics in hybrids increases with increasing numbers of back crosses. The same trend was confirmed for fruit shape and color (Fig. 1A). Also, NPT II-negative segregants of the F1, $\mathrm{BC} 1$, and $\mathrm{BC} 2$ progeny showed ca. one week delay in the development of flowers and fruits relative to their NPT II-positive counterparts under conditions of HDP, whereas no significant difference was noticed under conditions of LDP $(P<0.001)$. 


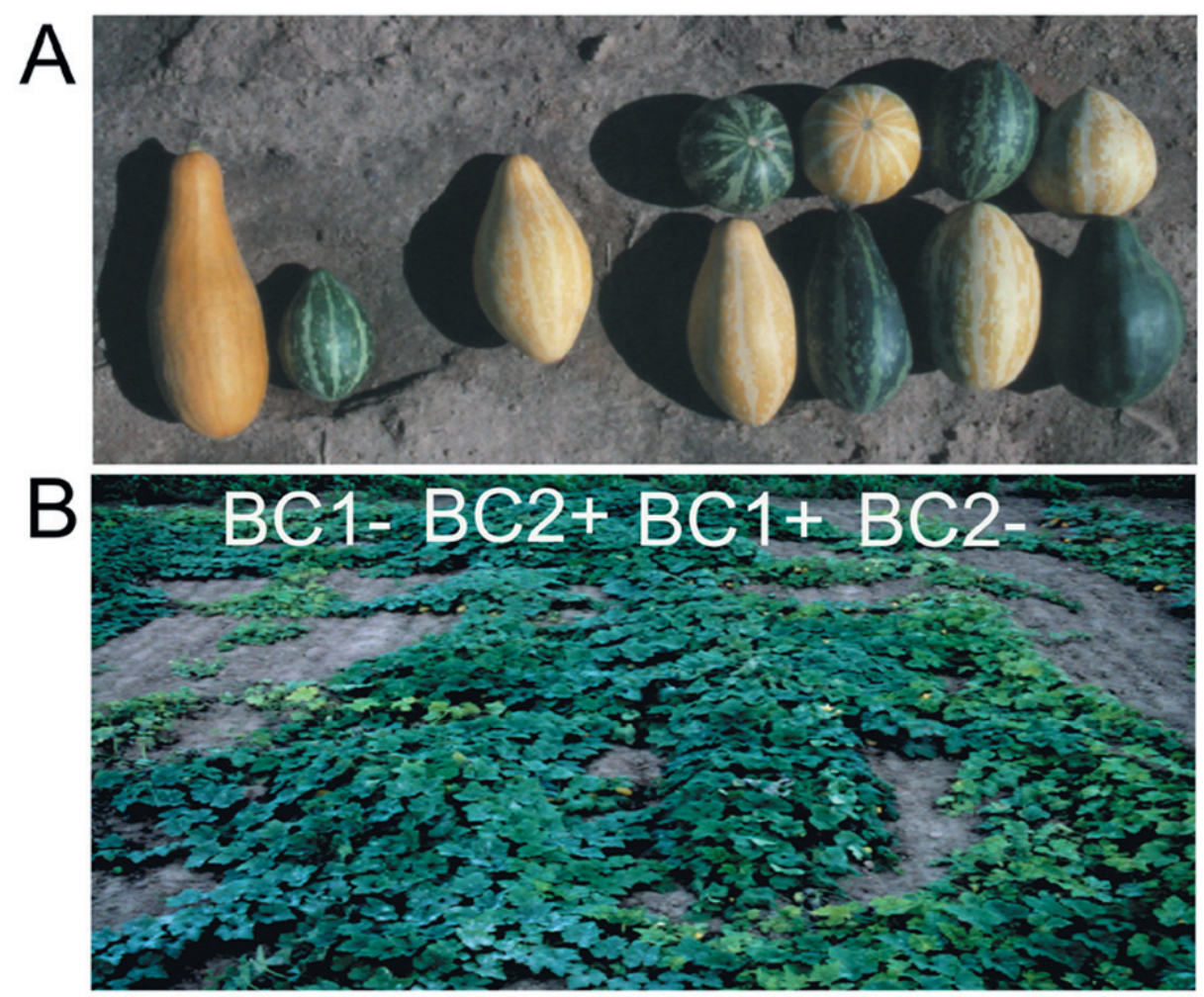

Figure 1. Shoot growth and fruits of $C$. texana and $C$. texana $\times$ CZW-3 hybrids. (A) Eight distinct fruits of BC1 hybrids (extreme right) are compared with one fruit of CZW-3 (extreme left), C. texana (second to the left), and F1 hybrids (third to the left). (B) Vigor of nontransgenic $\mathrm{BC} 1$ (extreme left row) and $\mathrm{BC} 2$ (extreme right row), and transgenic $\mathrm{BC} 1$ (central right row) and $\mathrm{BC} 2$ (central left row) hybrid segregants under conditions of high disease pressure of CMV, ZYMV, and WMV. (This figure is available in color in electronic form at www.edpsciences.org/ebr).

\section{C. texana hybrid progeny expressing the CP genes of CMV, ZYMV, and WMV exhibit resistance to these three aphid-borne viruses}

The reaction of C. texana, transgenic squash CZW-3, and three generations of $C$. texana $\times \mathrm{CZW}-3$ hybrids to virus infection was compared under conditions of LDP and HDP. Progress of disease, following aphid-vectored virus infection, was assessed by visual monitoring of symptom development. The incidence of CMV, ZYMV, and WMV was examined at the end of the trial period by ELISA. Our data indicate that, across all trials, transgenic plants were highly resistant to the three target viruses, as evidenced by a lack of systemic infection, while nontransgenic plants were susceptible. The 1997 disease progress curves illustrate the differential reaction among genotypes (Fig. 2).

All C. texana and NPT II-negative hybrid segregants (F1-, BC1-, and BC2-) developed systemic symptoms as early as $42 \mathrm{dpp}$ (= days post-transplanting) in plots exposed to HDP (Fig. 2A), as opposed to $73 \mathrm{dpp}$ for plants in plots exposed to LDP (Fig. 2B). Systemic symptoms consisted of severe mosaic, chlorosis, vein banding, and stunted growth. In contrast, transgenic squash CZW-3 and NPT II-positive segregants $(\mathrm{F} 1+, \mathrm{BC} 1+$, and $\mathrm{BC} 2+)$ did not develop systemic symptoms upon infection by $\mathrm{CMV}$, ZYMV and WMV, regardless of the level of disease pressure (Fig. 2). As previously reported (Fuchs et al., 1998; Tricoli et al., 1995), the majority of transgenic squash CZW-3 developed chlorotic dots (65 and 72\% under LDP and HDP, respectively) that were mainly confined to older leaves. Interestingly, a number of transgenic hybrid segregants showed the same localized reaction (18 and $46 \%$ of the $\mathrm{F} 1,4$ and $34 \%$ of the $\mathrm{BC} 1$, and 1 and $26 \%$ of the $\mathrm{BC} 2$ progeny under conditions of LDP and HDP, respectively). This lack of systemic symptom development upon infection by CMV, ZYMV, and WMV, regardless of the level of disease pressure, indicates that resistance to the three target viruses was equally high in transgenic squash CZW-3 than in transgenic hybrids. 


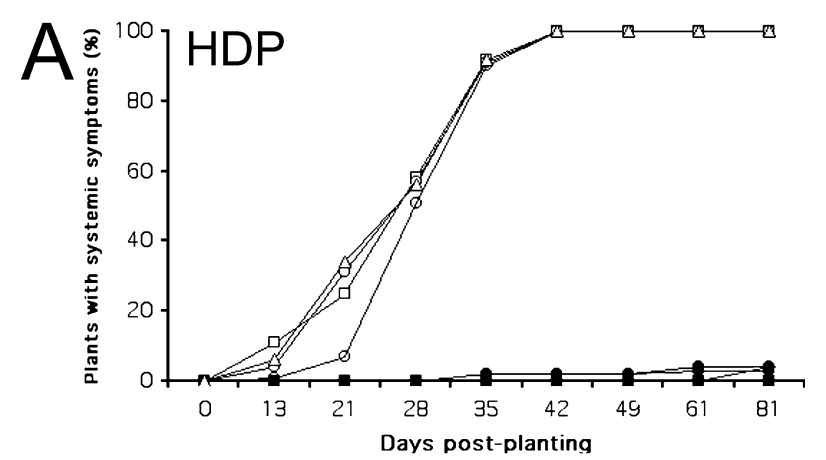

Table 2. ELISA detection of CMV, ZYMV, and WMV in C. texana, transgenic squash $\mathrm{CZW}-3$, and transgenic and nontransgenic segregants of three $C$. texana $\times \mathrm{CZW}-3$ hybrid progeny under field conditions of low and high disease pressure in 1997.

\begin{tabular}{|c|c|c|c|c|}
\hline \multirow[t]{2}{*}{ Genotype $^{1}$} & \multirow{2}{*}{$\begin{array}{c}{ }^{1} \text { Transgenic } \\
\text { Status }^{2}\end{array}$} & \multirow{2}{*}{$\begin{array}{c}\text { Level of Viral } \\
\text { Disease } \\
\text { Pressure }^{3}\end{array}$} & \multicolumn{2}{|c|}{ No Plants \%ELISA-Positive } \\
\hline & & & Tested & Plants ${ }^{4}$ \\
\hline \multirow[t]{2}{*}{ C. texana } & - & low & 50 & 89 \\
\hline & & high & 60 & 100 \\
\hline \multirow[t]{2}{*}{ CZW-3 } & + & low & 50 & 3 \\
\hline & & high & 60 & 8 \\
\hline \multirow[t]{4}{*}{$\mathrm{F} 1$} & - & low & 50 & 97 \\
\hline & & high & 50 & 100 \\
\hline & + & low & 50 & 6 \\
\hline & & high & 60 & 7 \\
\hline \multirow[t]{4}{*}{$\mathrm{BC} 1$} & - & low & 60 & 87 \\
\hline & & high & 83 & 100 \\
\hline & + & low & 50 & 6 \\
\hline & & high & 60 & 9 \\
\hline \multirow[t]{4}{*}{$\mathrm{BC} 2$} & - & low & 90 & 81 \\
\hline & & high & 100 & 100 \\
\hline & + & low & 50 & 6 \\
\hline & & high & 56 & 10 \\
\hline
\end{tabular}

Figure 2. Disease progress curves on $C$. texana and three $C$. texana $\times \mathrm{CZW}-3$ hybrids. C. texana $(\square)$, transgenic squash CZW-3 $(\mathbf{\square})$, transgenic F1 $(\diamond), \mathrm{BC} 1(\bullet)$, and BC2 $(\boldsymbol{\Delta})$, and nontransgenic $\mathrm{F} 1(\diamond), \mathrm{BC} 1(\mathrm{O})$, and $\mathrm{BC} 2(\triangle)$ segregants were analyzed. A total of 110 plants were tested for each genotype, except for BC1- (144 individuals) and BC2- (186 individuals). (A) Test plants were exposed to high disease pressure in 1997. (B) Test plants were exposed to low disease pressure in 1997.

ELISA substantiated the low incidence of the three target viruses in transgenic plants, including transgenic hybrid segregants, whereas CMV, ZYMV, and WMV were prevalent in nontransgenic plants regardless of the level of disease pressure (Tab. 2). The percentage of virus-infected plants was significantly higher for nontransgenic (NPT II ELISA-negative) than for transgenic (NPT II ELISA-positive) genotypes $(P<0.001)$. These results confirm that virus resistance was transferred from transgenic squash CZW-3 to hybrids as an inheritable trait, and that all transgenic hybrid segregants retained resistance in the $\mathrm{F} 1, \mathrm{BC} 1$, and $\mathrm{BC} 2$ progeny.

A few transgenic plants $(2-10 \%, 2-11 / 110)$ developed systemic symptoms consisting of foliar mosaic and chlorosis late in the growing season (Fig. 2A and B). The causative viral agents were searched in these plants by ELISA, and single and multiple infections of the aphidborne PRSV, and the nematode-borne Tomato ringspot virus (ToRSV) and Tobacco ringspot virus were revealed.

\footnotetext{
${ }^{1}$ See Table 1 for a detailed description of each genotype.

2 Transgenic (+) and nontransgenic (-) segregants of hybrid progeny were identified by NPT II ELISA.

${ }^{3}$ See Experimental Protocol for the achievement and maintainance of the two levels of selection pressure.

${ }^{4}$ Data represent the cumulative number of ELISA-positive plants for CMV, ZYMV, and/or WMV by 73 and $81 \mathrm{dpp}$ for conditions of low and high disease pressure, respectively, over the total number of plants tested. Infected plants had $\mathrm{OD}_{405 \mathrm{~nm}}$ readings at least 5 times higher (0.581 vs. 0.093 for ZYMV, 0.504 vs. 0.098 for WMV, and 0.495 vs. 0.095 for CMV) than control plants after 30 min substrate hydrolysis. Noninfected transgenic plants had $\mathrm{OD}_{405 \mathrm{~nm}}$ readings of 0.138 for ZYMV, 0.122 for WMV, and 0.127 for CMV. A few ELISA-positive transgenic hybrid segregants (6-10\%) showed localized chlorotic dots in younger leaves. Differences between nontransgenic (NPT II ELISA-negative) and transgenic (NPT II ELISApositive) genotypes were significant $(P<0.001)$.
}

\section{C. texana hybrid progeny with the CP genes of CMV, ZYMV, and WMV have an increased fitness over nontransgenic plants under conditions of high disease pressure}

Some fitness components of $C$. texana, transgenic squash $\mathrm{CZW}-3$, and three generations of $C$. texana $\times \mathrm{CZW}-3$ 

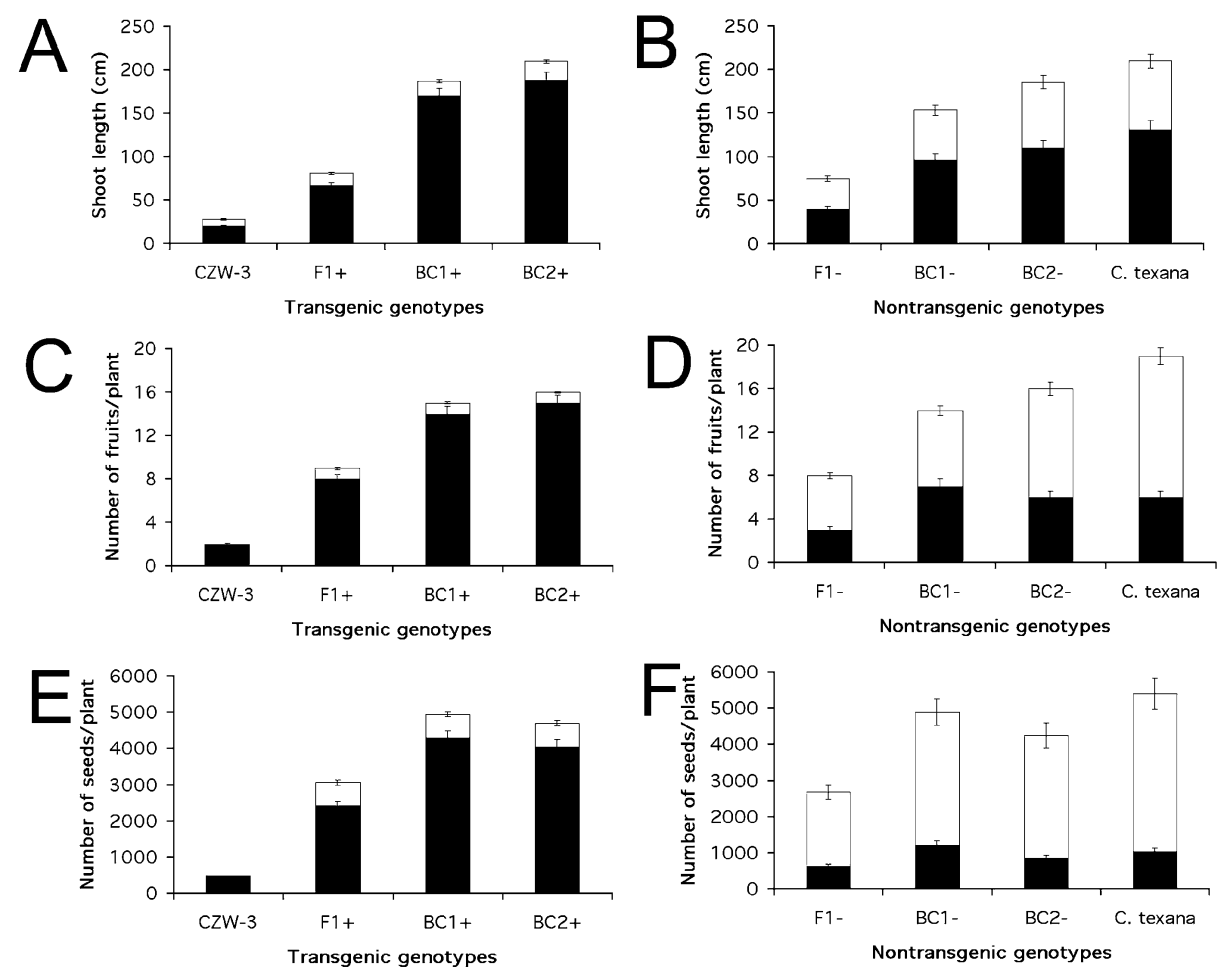

Figure 3. Fitness characteristics of $C$. texana, transgenic squash CZW-3, and three $C$. texana $\times$ CZW-3 hybrid progeny under conditions of low $(\square)$ and high ( $\square$ ) disease pressure in 1997. Transgenic (left panels) and nontransgenic (right panels) segregants of each genotype were differentiated. Mean values are indicated \pm SD. See Table 2 for the number of plants tested. (A, B) Shoot length. (C, D) Number of mature fruits per plant. (E, F) Number of viable seeds per fruit.

hybrid progeny were compared under conditions of LDP and HDP (Fig. 3). Shoot length was measured as a parameter indicative of plant growth and vigor. As expected, the level of disease pressure dramatically affected the performance of nontransgenic hybrid segregants and $C$. texana, with NPT II-negative hybrids having significantly smaller shoots under conditions of HDP compared with conditions of LDP $(P<0.001)$ (Fig. 1B and 3B). In contrast, the level of disease pressure did not significantly affect the shoot length of transgenic hybrid segregants (Fig. 3A). A positive correlation was also found between shoot length and the number of back crosses (Fig. 3A and B).

Fitness was also evaluated by analyzing the production of mature fruits and viable seeds as parameters indicative of reproductibility. As previously noted for shoot length, nontransgenic segregants produced significantly less fruits (Fig. 3D) and seeds (Fig. 3F) under conditions of HDP compared with LDP $(P<0.001)$. In contrast, the production of fruits (Fig. 3C) and seeds (Fig. 3E) in transgenic hybrid segregants was not significantly affected by the level of disease pressure $(P=0.09)$. As expected, a positive correlation was found between the production of fruits and the number of back crosses (Fig. 3C and D). The same positive correlation was also noticed for the production of seeds, although BC2 hybrids had slightly smaller values than $\mathrm{BC} 1$ hybrids and $C$. texana (Fig. $3 \mathrm{E}$ and F).

Linear models were fitted for the data on the three parameters measured (shoot length, number of fruits and number of seeds per plant) to analyze the effect of genotype, transgenic status (transgenic vs. nontransgenic segregants), treatment (LDP vs. HDP), and their interactions. The linear models fitted were: $\mathrm{Y}=\mu+\gamma_{\mathrm{i}}+$ $\gamma v_{\mathrm{ij}}+\tau_{\mathrm{k}}+\gamma \tau_{\mathrm{ik}}+\gamma \nu \tau_{\mathrm{ijk}}$. Analysis of variance for the data on shoot length indicated that the interactions were not significant and that most of the variation observed was due to the main effects of genotype and treatment. Further, analysis of variance for the data on number of fruits and number of seeds per plant indicated that the interaction between treatment and transgenic status within genotypes was significant $(P<0.001)$, indicating a combined effect of these two factors in the response variables measured. 
Table 3. Development of $C$. texana $\times \mathrm{CZW}-3$ hybrids with $C$. texana-type characteristics and resistance to CMV, ZYMV, and WMV.

\begin{tabular}{lcc}
\hline \hline Genotype $^{1}$ & $\begin{array}{c}\text { Virus-resistant } \text { C. texana-type plants/ } \\
\text { Total number of plants tested }\end{array}$ & $\%^{2}$ \\
\hline F1 & $0 / 426$ & 0 \\
BC1 & $9 / 459$ & 2 \\
BC2 & $18 / 296$ & 6 \\
\hline
\end{tabular}

${ }^{1}$ See Table 1 for a description.

${ }^{2}$ Cumulative percentage of plants with a viney habit (shoot length $>2 \mathrm{~m}$ ), numerous small green fruits ( $>15 /$ plant) with a round and oblate or pear-like shape, and light green or white stripes, and resistance to CMV, ZYMV, and WMV. Fruits were counted at the end of the growing seasons for each plant. Data for F1 hybrids are from 1995 to 1997, for BC1 hybrids from 1996 and 1997, and for BC2 hybrids from 1997.

\section{Hybrids with C. texana-type characteristics and resistance to CMV, ZYMV, and WMV develop after a single generation of hybridization and back crossing}

Transgenic and nontransgenic C. texana $\times \mathrm{CZW}-3$ hybrid progeny were examined to determine how many back crosses were necessary to recover hybrids with $C$. texana characteristics and resistance to CMV, ZYMV, and WMV. Test plants exposed to conditions of LDP and HDP were scored for growth habit, fruit characteristics, and resistance to the three target viruses, as measured by the absence of systemic symptoms and negative ELISA results for CMV, ZYMV, and WMV. Across all field experiments from 1995 and 1997, virus-resistant hybrids with a viney habit (shoot length $>2 \mathrm{~m}$ ) and small green fruits with a round and oblate or pear-like shape, and light green or white stripes were considered as potential candidates. These plants were further evaluated for fruit production (Tab. 3). A few of the BC1 $(2 \%, 9 / 459)$ and BC2 $(6 \%, 19 / 296)$ had numerous fruits (>15/plant) like C. texana (Fuchs et al., 2004), indicating that a single generation of hybridization and back crossing is enough to recover hybrids with $C$. texana-type properties and resistance to CMV, ZYMV, and WMV.

\section{DISCUSSION}

This is the first report on the comparison of some fitness components of a wild relative and three generations of fertile hybrids resulting from a cross with a virus-resistant transgenic crop. We found that the CP transgenes of CMV, ZYMV, and WMV were stably inherited in F1, BC1, and
BC2 hybrids between transgenic CZW-3 and C. texana, and provided resistance to these three viruses in transgenic segregants of hybrid progeny. Furthermore, BC1 and BC2 grew more vigorously, produced a greater number of mature fruits and viable seeds, under conditions of HDP. F1 transgenic hybrids produced substantially more fruits and seeds than $C$. texana under conditions of HDP but grew less vigorously. In contrast, under conditions of LDP, C. texana outperformed the three hybrid progeny in regard to the parameters measured, and nontransgenic hybrids, despite a lack of resistance to CMV, ZYMV, and WMV, performed similarly to transgenic hybrids, suggesting no apparent cost associated to the expression of the three CP genes.

Spencer and Snow (2001) previously documented some fitness components of F1 hybrids of transgenic squash Freedom II and C. texana and reported an average lower fecundity and seed production of F1 hybrids compared with C. texana. We found a higher seed production for F1 hybrids compared with $C$. texana under conditions of HDP but not LDP. This apparent discrepancy could be attributed to the fact that experimental conditions similar to our LDP settings were used in the former study. Interestingly, a higher biomass of F1 hybrids between transgenic sugar beets resistant to Beet necrotic yellow vein virus (BNYVV) and Swiss chard compared with controls was also reported under conditions of LDP (Bartsch et al., 2001).

In our studies, a single generation of hybridization and back crossing was enough to recover a few $(2 \%, 9 /$ 459) hybrids with typical $C$. texana-type characteristics and resistance to the three target viruses. Mikkelsen et al. (1996) also identified fertile glufosinate tolerant Brassica rapa-like plants upon herbicide selection as early as the first back cross generation. That study involved transgenic oilseed rape (Brassica napus) as initial donor of transgenic pollen. Similarly, the CP gene of BNYVV was stably inherited in hybrids between transgenic sugar beet and wild beets, and transgenic wild beet hybrids were resistant to BNYVV upon inoculation with a viruliferous zoospore suspension of the fungus vector Polymyxa betae (Dietz-Pfeilestetter and Kirchner 1998).

Hybridization has been proposed to play an important role in the evolution of invasiveness (Ellstrand and Schierenbeck, 2000). Eighteen different taxa of wild squash relatives are native to the United States and Mexico (Wilson, 1990). However, only populations of C. texana and $C$. pepo ssp. ovifera var. ozarkana (C. ozarkana) occur in agricultural settings in the United States. C. texana and C. ozarkana differ only in their distribution; C. texana is found in Texas while C. ozarkana is found in 
the Mississippi Valley. C. ozarkana has been described as an aggressive weed in soybean and cotton fields in Arkansas, Louisiana, and Mississippi (Boyette et al., 1984; McCreight and Staub, 1999; Oliver et al., 1983; Weideman and Templeton, 1988). We found that the dissemination of CP transgenes triggered the development of virus-resistant $C$. texana in experimental settings. Will $\mathrm{CP}$ transgene movement have a potential ecological impact by affecting, for example, individual C. texana or C. ozarkana, or changing the dynamics of their natural communities, if these wild squash relatives are pollinated by bees from production fields of virus-resistant transgenic squash? Along this line, could C. texana consequently become a noxious weed pest? Or, could $C$. ozarkana exhibit exacerbated weediness potential? Our data suggest that virus-resistant $C$. texana may have a clear advantage compared with virus-susceptible $C$. texana in situations where viruses are severely limiting the growth and reproductive potential of $C$. texana. In other words, the level of viral disease pressure, among other factors potentially regulating or limiting wild squash populations, is paramount to determine whether $C$. texana that acquire the CP transgenes could have a selective advantage. Fitness advantages have also been reported for hybrids of oilseed rape (Gueritaine et al., 2002) and wild radish expressing the bar gene upon herbicide selection, and for hybrids of cultivated and wild sunflowers (Snow et al., 2003) expressing the crylAc gene upon lepidopteran pressure. In contrast, a transgene conferring resistance to white mold had little fitness effects in hybrids between cultivated and wild sunflowers (Burke and Rieseberg, 2003).

There is currently limited information on the incidence of viruses in wild crop relatives, including squash. Although earlier work seems to indicate that wild plants are commonly infected by viruses (McClement and Richards, 1956), only fragmented information is available on the occurrence of viruses in wild populations in natural habitats (Duffus, 1971; Kelley, 1993). For example, CMV was recovered from $28 \%$ (39/137) of the wild plant species sampled in a cucurbit-growing area near Montfavet, France (Quiot et al., 1979). Interestingly, the majority of CMV-infected plants were symptomless. More recently, a high incidence of infection by Beet western yellows virus, Cauliflower mosaic virus, Turnip mosaic virus (TuMV), and Turnip yellow virus (TYMV) was documented in wild cabbage in England (Raybould et al., 1999). Similarly, 5-6 different viruses were found in Brassica nigra (Thurston et al., 2001) and Brassica rapa ssp. sylvestris (Pallett et al., 2002) with various frequencies in England. In contrast, a survey of wild beet populations in North-Eastern Italy for infection by BNYVV showed that none of the wild beet plants reacted positively for BNYVV in ELISA (Bartsch et al., 1996). Similarly, limited viral infection was found in wild squash populations, which were assayed for the presence of the four major viruses challenging squash (Quemada, 1998; Quemada et al., 2002), including the three target viruses of our study. The percentage of virus-infected plants ranged from 0 to $0.75 \%$, with the majority being virus-free, suggesting a low incidence of viruses in wild squash species. Extensive surveys are further needed to verify these preliminary results, particularly in locations nearby cultivated fields that are subjected to severe virus infection because of potential exposure to aphid-mediated virus spread. Taken together, there is little, if any, evidence so far that the introduction of virus resistance could provide a tremendous selective advantage to wild squash species, thereby increasing their ability to become established as noxious weed pests or exacerbate their weediness potential.

There is also fragmented information on the effect of viruses on the dynamics and evolution of wild crop relatives. Some reports, however, clearly indicate that viruses can have a deleterious impact. For example, ToRSV reduces flower production and fresh weight of dandelion (Powell et al., 1992). Also, CMV inhibits the vegetative growth and reproductive potential of purslane (Friess and Maillet, 1996), and reduces the competitive capacity and reproduction of chickweed (Friess and Maillet, 1997). These studies targeted wild plants that are not capable of hybridization with crops. Recently, it has been shown that TuMV and TYMV reduce the survival, growth, and reproduction of wild cabbage, which can hybridize with cultivated cabbage (Maskell et al., 1999). Since our findings clearly demonstrate the importance of the level of viral disease pressure on the fate of wild-squash hybrids, it becomes clear that there is a need for information on the incidence and effect of viruses in natural populations of wild plants that are sexually compatible with domesticated crops.

Squash production is affected worldwide by viruses that substantially reduce yield and fruit quality (Blancard et al., 1994; Zitter et al., 1996). Virus-resistance genes have been incorporated into squash elite cultivars by genetic engineering as well as by conventional breeding techniques (Munger, 1993; Tricoli et al., 1995). Since escape of host-derived genes and transgenes is identical (Hokanson et al., 1997), host-derived and genetically engineered virus resistance traits are likely to be similarly transferred from cultivated squash to wild relatives. Thus, no difference is expected between genetically engineered 
virus resistance and similar virus resistance bred into squash by conventional techniques regarding environmental risks associated with gene flow. In particular, fitness components should be similarly affected by virus resistance whether conferred by genetic engineering or conventional crop genes.

Virus-resistant transgenic and conventionally bred squash offer numerous benefits to agriculture that are of agronomical, economical, epidemiological, and environmental importance (Fuchs and Gonsalves, 1995, 1997; Fuchs et al., 1998; Klas et al., 1994; Quemada, 1998; Tricoli et al., 1995). Although it is likely that introgression of the virus-resistant traits will occur into wild squash, additional data are needed on the occurrence of viruses in populations of wild and weedy squash species in their natural habitats for a complete assessment of the environmental consequences of gene flow.

\section{MATERIALS AND METHODS}

\section{Plant material}

Transgenic squash (Cucurbita pepo ssp. ovifera var. ovifera) line CZW-3 expressing the CP genes of CMV, ZYMV, and WMV, as well as the marker gene nptII, was obtained by Agrobacterium tumefaciens-mediated transformation (Tricoli et al., 1995). It was used as donor of transgenic pollen. Expression of each CP gene was driven by the Cauliflower mosaic virus (CaMV) $35 \mathrm{~S}$ promoter, part of the intergenic region of RNA 3 of CMV strain $\mathrm{C}$ used as leader sequence, and the nopaline synthase or the CaMV 35S terminator sequences (Tricoli et al., 1995).

The sexually compatible wild relative $C$. pepo spp. ovifera var. texana (C. texana) was used as recipient of transgenic pollen. C. texana is a geographically restricted wild squash species (Decker, 1988; Kirkpatrick and Wilson, 1988; Wilson, 1990) that does not express the CP genes of CMV, ZYMV, and WMV, nor the nptII gene (Fuchs et al., 2003).

Hybrids of $C$. texana and CZW-3 were obtained by hand pollination in the greenhouse by depositing pollen of single stamens of donors of transgenic pollen onto single pistils of $C$. texana. Pollinations were usually carried out in the summer. C. texana $\times \mathrm{CZW}-3$ hybrids were developed from 1994 through 1997, one generation per year, and tested in the field the year following their development.

Seeds of transgenic squash CZW-3, C. texana, and $C$. texana $\times \mathrm{CZW}-3$ hybrids were sown directly in artificial medium.

\section{Mechanical inoculations of C. texana}

A few C. texana seedlings were inoculated by rubbing Corundum-dusted cotyledons and expanded leaves with diluted inoculum. At this development stage, C. texana seedlings showed 2-3 expanded leaves. The inoculum was prepared with 1:50 dilutions of crude sap from either CMV, ZYMV, or WMV-infected squash cv. President. Strains Fny of CMV, FL of ZYMV, and NY of WMV were used as inocula (Fuchs et al., 1998). Inoculated plants were maintained in screenhouses one week prior to transplanting.

\section{Identification of transgenic segregants by NPT II ELISA}

Expression of the NPT II protein was detected in segregating $C$. texana $\times \mathrm{CZW}-3$ hybrid progeny by ELISA using commercial $\gamma$-globulins $(5$ Prime $\longrightarrow 3$ Prime, Boulder, CO, USA). Cotyledonary tissue from germinating seedlings was used as antigen. Conditions of the test and interpretation of the results were as described previously (Fuchs and Gonsalves, 1995; Fuchs et al., 1998; Tricoli et al., 1995). This approach allowed us to conveniently and reliably screen a large population of plants at an early developmental stage.

\section{Experimental design and field layout}

Field experiments were carried out under permits issued by APHIS-USDA in 1995 and 1996. Permits were not needed in 1997 because transgenic squash line CZW-3 received exemption status in 1996 (Acord, 1996). Isolated field sites were selected on different experimental farms at the New York State Agricultural Experiment Station in Geneva, NY, USA. Plants were tested under conditions of LDP or HDP. Field plots with LDP were at least $2 \mathrm{~km}$ apart from those with HDP.

Conditions of LDP were obtained by transplanting healthy plants to locations isolated from sources of aphidtransmissible viruses. This approach was used to prevent the introduction of aphid-borne viruses from outside our fields. Also, plants that became infected early in the growing season, i.e. before flowering, via aphids were eliminated so that they would not serve as virus source for secondary spread. Plants that became infected after flowering and fruiting were not eliminated.

Conditions of HDP were obtained by transplanting a majority (80\%) of healthy plants and fewer (20\%) 
C. texana that were mechanically-inoculated in the greenhouse with either CMV, ZYMV, or WMV. Virus-infected C. texana were transplanted at determined locations (4 plants per row) to facilitate an uniform distribution of the three inocula. Infected $C$. texana served as virus source for secondary spread vectored by indigenous populations of aphids.

A complete randomized block design was used to compare fitness under conditions of LDP and HDP with 5 replicates of each genotype. Genotypes were randomly allocated into 4 blocks. Plants were $1 \mathrm{~m}$ apart and $2 \mathrm{~m}$ between rows. No insecticides were used since one of the objectives was to evaluate resistance to aphid-vectored infections.

\section{Field data collection}

The following data were collected for each C. texana, transgenic squash CZW-3, and hybrid progeny: (i) flowering and fruiting phenology, (ii) resistance to CMV, ZYMV, and WMV, (iii) plant vigor, and (iv) fruit production. The temporal appearance of flowers and fruits was visually analyzed every $3-5$ days. Resistance to viruses was monitored by visual assessment of symptom development every 3-7 days, and by ELISA using $\gamma$-globulins. Leaf samples in position $1-5$ at the apical end of the longest shoot/vine of each plant were collected at the end of the growing season and stored in zip-lock bags at $-20{ }^{\circ} \mathrm{C}$ until processed. Processing of leaf tissue, $\gamma$-glogulins, conjugates, ELISA conditions, and data interpretation were as described previously (Fuchs and Gonsalves, 1995; Fuchs et al., 1998).

Shoot length, measured as length of the longest vine, was taken as one of the parameters indicative of plant growth and vigor. Measurements were done on all plants once at mid-season.

Mature fruits and viable seeds were counted as parameters indicative of reproductibility. Fruits were maintained on the plants throughout each growing season to simulate unmanaged field conditions. Mature fruits of all plants were counted at the end of the growing seasons and scored for shape and color.

Seeds were extracted from 10 randomly selected fruits of each genotype and cleaned. Viable seeds were selected using a blower that creates a vertically-oriented air turbulence in a polypropylene chamber, providing conditions for seed selection based on weight. Light immature seeds were blown up and collected in upper side compartments of the chamber while heavy mature seeds stayed in the bottom. Viable seeds were counted and stored for germination.

\section{Statistical analyses}

Data on shoot length and fruit and seed production, collected under conditions of LDP and HDP, were summarized and descriptive statistics were obtained for each data set. Analysis of variance, multivariate analysis, and regression analysis were conducted using $\mathrm{SAS}^{\circledR}$ (Statistical Analysis System, SAS Institute Inc., Raleigh, NC, USA) to detect treatment differences and study the relationship between variables.

\section{ACKNOWLEDGMENTS}

We thank Dr. David M. Tricoli of the Asgrow Seed Company for kindly providing us with seeds of transgenic squash CZW-3 and C. texana. We are grateful to Vânia Souza, Sheri Ecker-Day, and George Mittak for their excellent help, and to William Boone and Jonathan Douglas. We thank Dr. John Barnard for the statistical analyses, and Drs. L.M. Yepes and H. Quemada for critical reading of the manuscript. This work was partially supported by a competitive grant from USDA's Biotechnology Risk Assessment Research Grant Program (No. 95-33120-1878). This work is dedicated to George Mittak who suddenly passed away in November of 2001 .

Received August 25, 2003; accepted December 15, 2003.

\section{REFERENCES}

Acord BD (1996) Availability of determination of nonregulated status for a squash line genetically engineered for virus resistance. Fed. Reg. 61: 33484-33485

Bartsch D, Schmidt M, Pohl-Orf M, Haag C, Schuphan I (1996) Competitiveness of transgenic sugar beet resistant to beet necrotic yellow vein virus and potential impact on wild beet populations. Mol. Ecol. 5: 199-205

Bartsch D, Brand U, Morak C, Pohl-Orf M, Schuphan I, Ellstrand NC (2001) Biosafety of hybrids between transgenic virus-resistant sugar beet and Swiss Chard. Ecol. Appl. 11: 142-147

Blancard D, Lecoq H, Pitrat M (1994) Cucurbit Diseases: Observation, identification and control. Wiley and Sons, New York, NY

Boyette G, Templeton E, Oliver LR (1984) Texas gourd (Cucurbita texana) control. Weed Sci. 32: 649-655

Burke JM, Rieseberg LH (2003) Fitness effects of transgenic disease resistance in sunflowers. Science 300: 1250

Dale J (1992) Spread of engineered genes to wild relatives. Plant Physiol. 100: 13-15 
Fitness of virus resistance in squash

Decker DS (1988) Origin(s), evolution, and systematics of Cucurbita pepo (Cucurbitaceae). Econ. Bot. 42: 4-15

Dietz-Pfeilestetter A, Kirchner M (1998) Analysis of gene inheritance and expression in hybrids between transgenic sugar beet and wild beets. Mol. Ecol. 7: 1693-1700

Duffus JE (1971) Role of weeds in the incidence of virus diseases. Annu. Rev. Phytopathol. 9: 319-340

Ellstrand NC, Schierenbeck KA (2000) Hybridization as a stimulus for the evolution of invasiveness in plants? Proc. Natl. Acad. Sci. USA 97: 7043-7050

Ellstrand NC, Prentice HC, Hancock JF (1999) Gene flow and introgression from domesticated plants into their wild relatives. Annu. Rev. Ecol. Syst. 30: 539-563

Friess N, Maillet J (1996) Influence of cucumber mosaic virus infection on the intraspecific competitive ability and fitness of purslane. New Phytol. 132: 103-111

Friess N, Maillet J (1997) Influence of cucumber mosaic virus infection on the competitive ability and reproduction of chickweed (Stellaria media). New Phytol. 135: 887-674

Fuchs M, Gonsalves D (1995) Resistance of transgenic hybrid squash ZW-20 expressing the coat protein genes of zucchini yellow mosaic virus and watermelon mosaic virus 2 to mixed infections by both potyviruses. Bio/Tech. 13: 14466-14473

Fuchs M, Gonsalves D (1997) Genetic Engineering. In Rechcigl NA, Rechcigl JE, eds, Environmentally Safe Approcahes to Crop Disease Control, CRC Press, Boca Raton, FL, pp 333-368

Fuchs M, Tricoli DM, McMaster JR, Carney KJ, Schesser M, McFerson JR, Gonsalves D (1998) Comparative virus resistance and fruit yield of transgenic squash with single and multiple coat protein genes. Plant Dis. 82: 1350-1356

Fuchs M, Chirco EM, Gonsalves D (2004) Movement of coat protein genes from a commercial virus-resistant transgenic squash into a wild relative. Environ. Biosafety Res. 3: 5-16

Gonsalves D (1998) Control of papaya ringspot virus in papaya: A case study. Annu. Rev. Phytopathol. 36: 415-437

Grumet R (1994) Development of virus resistant plants via genetic engineering. Plant Breeding Rev. 12: 47-79

Gueritaine G, Sester M, Eber F, Chèvre AM, Darmency $H$ (2002) Fitness of backcross six of hybrids between transgenic oildseed rape (Brassica napus) and wild radish (Raphanus raphanistrum). Mol. Ecol. 11: 1419-1426

Hancock JF, Grumet R, Hokanson SC (1996) The opportunity of escape of engineered genes from transgenic crops. HortSci. 31: 1080-1085

Hokanson SC, Hancock JF, Grumet R (1997) Direct comparison of pollen-mediated movement of native and engineered genes. Euphytica 96: 397-403

Kareiva P, Morris W, Jacobi CM (1994) Studying and managing the risk of cross-fertilization between transgenic crops and wild relatives. Mol. Ecol. 3: 15-21

Kelley SE (1993) Viruses and the advantage of sex in Anthoxanthum odoratum: A review. Plant Species Biol. 8: 217-223
Kirkpatrick KJ, Wilson H (1988) Interpecific gene flow in Cucurbita: C. texana vs. C. pepo. Am. J. Bot. 75: 519-527

Klas FE, Fuchs M, Gonsalves D (1994) Spatial analysis as a tool to evaluate virus resistance in a transgenic crop. Phytopathol. 84: 1372

Maskell LC, Raybould AF, Cooper JI, Edwards ML, Gray AJ (1999) Effects of turnip mosaic virus and turnip yellow mosaic virus on the survival, growth and reproduction of wild cabbage (Brassica oleracea). Ann. appl. Biol. 135: 401-407

McClement WD, Richards M (1956) Virus in wild plants. Can. J. Bot. 24: 793-799

McCreight JD, Staub J (1999) Report of the Cucurbit working group. In Traynor P, Westwood JH, eds, Proceedings of a Workshop on Ecological Effects of Pest Resistance Genes in Managed Ecosystems, Jan. 31-Feb. 3, ISB, Blacksburg, VA, pp 79-87

Medley TL (1994) Availability of determination of nonregulated status for virus resistant squash. Fed. Reg. 59: 64187-64189

Mikkelsen TR, Andersen B, Jørgensen RB (1996) The risk of crop transgene spread. Nature 380: 31

Munger HM (1993) Breeding for viral resistance in cucurbits. In Resistance to viral diseases of vegetables: Genetics and breeding, Timber Press, Portland, OR, pp 8-43

Oliver LR, Harrison SA, McClelland M (1983) Germination of Texas gourd (Cucurbita texana) and its control in soybean (Glycine max). Weed Sci. 31: 700-706

Pallett DW, Thurston MI, Cortina-Borja M, Edwards ML, Alexander M, Mitchell E, Raybould AF, Cooper JI (2002) The incidence of viruses in wild Brassica rapa ssp. sylvestris in southern England. Ann. Appl. Biol. 141: 163-170

Powell CA, Mountain WL, Derr MA (1992) Tomato ringspot virus reduces dandelion top weight and flower production under field conditions. HortScience 27: 273

Quemada H (1998) The use of coat protein technology to develop virus-resistant cucurbits. In Ives CL, Bedford BM, eds, Agricultural Biotechnology in International Development, CAB International, Wallingford, UK, pp 147-160

Quemada H, Strehlow L, Decker-Walters D, Staub J (2002) Case Study: Gene flow from commercial transgenic Cucurbita pepo to "wild" C. pepo populations. In Proceedings of the Scientific Methods Workshop on Ecological and Agronomic Consequences of Gene Flow from Transgenic Crops to Wild Relatives, March 5-6, 2002, Columbus, OH, pp 65-70, http://www.biosci.ohio-state.edu/ lspencer/ gene_flow.htm

Quiot JB, Marchoux G, Douine L, Vigouroux A (1979) Écologie et épidémiologie du virus de la mosaïque du concombre dans le sud-est de la France. V. Rôle des espèces spontanées dans la conservation du virus. Ann. Phytopath. 11: 325-348

Raybould A (1999) Transgenes and agriculture - going with the flow? Trends Plant Sci. 4: 247-248 
Raybould AF, Maskell LC, Cooper JI, Edwards ML, Gray AJ (1999) The prevalence and spatial distribution of viruses in natural populations of Brassica oleracea. New Physiol. 141: $265-275$

Rissler J, Mellon M (1996) The Ecological Risks of Engineered Crops, MIT Press, Cambridge, MA, pp 159

Sanford JC, Johnston SA (1985) The concept of parasitederived resistance - deriving resistance genes from the parasite's own genome. J. Theor. Biol. 113: 395-405

Snow AA, Palma PM (1997) Commercialization of transgenic plants: Potential ecological risks. BioScience 47: 86-96

Snow AA, Pilson D, Rieseberg LH, Paulsen MJ, Pleskac N, Reagon MR, Wolf DE, Selbo SM (2003) A Bt-transgene reduces herbivory and enhances fecundity in wild sunflowers. Ecol. Appl. 13: 279-286

Spencer LJ, Snow A (2001) Fecundity of transgenic wild-crop hybrids of Cucurbita pepo (Cucurbitaceae): implications for crop-to-wild gene flow. Heredity 86: 694-702
Thurston MI, Pallett DW, Cortina-Borja M, Edwards ML, Raybould AF, Cooper JI (2001) The incidence of viruses in wild Brassica nigra in Dorset (UK). Ann. Appl. Biol. 139: 277-284

Tricoli DM, Carney KJ, Russell PF, McMaster JR, Groff DW, Hadden KC, Himmel PT, Hubbard JP, Boeshore ML, Quemada HD (1995) Field evaluation of transgenic squash containing single and multiple coat protein gene constructs for resistance to cucumber mosaic virus, watermelon mosaic virus 2 , and zucchini yellow mosaic virus. Bio/Tech. 13: 1458-1465

Weidemann GJ, Templeton GE (1988) Efficacy and soil persistence of Fusarium solani f. sp. cucurbitae for control of Texas gourd (Cucurbita texana). Plant Dis. 72: 36-38

Wilson HD (1990) Gene flow in squash species. BioScience 40: 449-455

Zitter TA, Hopkins DL, Thomas CE (1996) Compendium of cucurbit diseases, APS Press, St Paul, MN

To access this journal online: www.edpsciences.org 